\title{
A new capybara from the late Miocene of San Juan Province, Argentina, and its phylogenetic implications
}

Esperanza Cerdeño, María E. Pérez, Cecilia M. Deschamps, and Víctor H. Contreras

Acta Palaeontologica Polonica 64 (1), 2019: 199-212 doi:https://doi.org/10.4202/app.00544.2018

A new hydrochoerine rodent, Cardiatherium calingastaense sp. nov. (Caviidae), is described based on the specimen INGEO-PV 87. It was recovered from the late Miocene Las Flores Formation, cropping out at the Puchuzum locality, San Juan Province, Argentina. The new species is based on a particular combination of characters, among which the following can be highlighted: $\mathrm{p} 4$ with internal fissures equally deep as in Cardiatherium paranense, secondary external fissure as in Cardiatherium patagonicum, and lacking the fifth internal fissure and supernumerary internal fissure, as in C. paranense; $\mathrm{m} 3$ with a conspicuous labial column in the posterior ramus of the second prism; very deep primary and secondary external fissures in upper cheek teeth, the former producing a labial strong step-shaped profile in M2; sagittal crest on the parietals; bullae small in ventral view; scars of the origin of the masseter medialis muscle with an anterior projection up to the level of the incisive foramen and the maxilla-premaxilla suture. The phylogenetic analysis supports the taxonomic proposal of creating a new species of Cardiatherium and shows $C$. calingastaense sp. nov. as the sister group of the other species of the genus. The lineage leading to the clade Cardiatherium + largest capybaras would have originated at least during the Chasicoan SALMA (early late Miocene). Cardiatherium calingastaense sp. nov. adds to the previous record of Cardiatherium chasicoense and Cardiatherium paranense in the late Miocene of San Juan and Mendoza provinces, respectively, thus increasing the diversity of capybaras in central-west Argentina.

Key words: Mammalia, Rodentia, Caviidae, Cardiatherium, systematics, phylogeny, late Miocene, Argentina.

Esperanza Cerdeño [espe@ mendoza-conicet.gob-ar], Instituto Argentino de Nivología, Glaciología y Ciencias Ambi-entales (IANIGLA), Centro Científico Tecnológico, CONICET Mendoza, Av. Ruiz Leal s/n, 5500, Mendoza, Argentina.María E. Pérez [mperez@mef.org.ar], Museo Paleontológico Egidio Feruglio, Av. Fontana 140, U9100GYO, Trelew, Argentina.Cecilia M. Deschamps [ceci@fcnym.unlp.edu.ar], Comisión de Investigaciones Científicas de la provincia de Buenos Aires, Argentina; División 
Paleontología Vertebrados, Unidades de Investigación Anexo Museo de La Plata, Facultad de Ciencias Naturales y Museo, Universidad Nacional de La

Plata, 122 y 60, 1900, La Plata, Argentina.Víctor H. Contreras [vcontre@unsj-cuim.edu.ar], Instituto de Geología Dr. Emiliano P. Aparicio (INGEO) y Depar-tamento Geología, FCEFN, Universidad Nacional de San Juan, Ignacio de la Roza y Meglioli, 5400 Rivadavia, San Juan, Argentina.

This is an open-access article distributed under the terms of the Creative Commons Attribution License (for details please see creativecommons.org), which permits unrestricted use, distribution, and reproduction in any medium, provided the original author and source are credited.

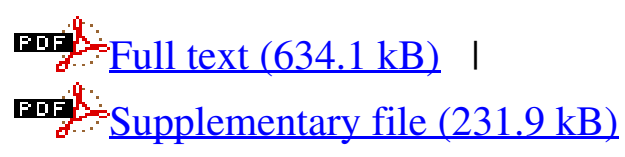

